\title{
Book Review: Remembrance and Forgiveness: Global and Interdisciplinary Perspectives on Genocide and Mass Violence
}

Amina Hadžiomerović

School of Global, Urban and Social Studies, RMIT University, Melbourne

Follow this and additional works at: https://digitalcommons.usf.edu/gsp

\section{Recommended Citation}

Hadžiomerović, Amina (2021) "Book Review: Remembrance and Forgiveness: Global and Interdisciplinary Perspectives on Genocide and Mass Violence," Genocide Studies and Prevention: An International

Journal: Vol. 15: Iss. 1: 134-136.

DOI:

https://doi.org/10.5038/1911-9933.15.1.1820

Available at: https://digitalcommons.usf.edu/gsp/vol15/iss1/11

This Book Review is brought to you for free and open access by the Open Access Journals at Digital Commons @ University of South Florida. It has been accepted for inclusion in Genocide Studies and Prevention: An International Journal by an authorized editor of Digital Commons @ University of South Florida. For more information, please contact digitalcommons@usf.edu. 


\title{
Book Review: Remembrance and Forgiveness: Global and Interdisciplinary Perspectives on Genocide and Mass Violence
}

Amina Hadžiomerović RMIT University

Melbourne, Australia

\author{
Remembrance and Forgiveness: Global and Interdisciplinary Perspectives on \\ Genocide and Mass Violence \\ Ajlina Karamehić-Muratović and Laura Kromják, eds. \\ London, Routledge, 2020 \\ 252 Pages; Price: $£ 120.00$ Hardcover
}

Reviewed by Amina Hadžiomerović

RMIT University

The volume Remembrance and Forgiveness: Global and Interdisciplinary Perspectives on Genocide and Mass Violence, edited by Ajlina Karamehić-Muratović and Laura Kromják, takes a reader on an intellectual and cultural journey across the sixteen chapters and six continents, exploring the social remnants of the post-Holocaust genocides and endeavours to reconcile. At the outset, the editors strongly anchor their stance in the moral imperative to remember, thus framing the two overarching themes of the volume by asking what is the relationship between remembrance and forgiveness; and how the notions of these two central concepts change and differ over time, across the cultures and contexts of genocide.

The book gives primacy to the local and cultural-rather than legal and general considerations of the genocides discussed - evident in the judicious and variegated selection of the chapter material that ranges from the studies of vernacular memorialisation initiatives to the semiotic analyses of the short films, newspaper articles, and literary representations of violence. Effectively, the volume bridges the dichotomic gap posed by the platitudinous question of whether it is easier to forgive or forget, through incisive analysis of the inextricable interdependency between the two; further solidifying the notion that "memory is a prerequisite to forgiving." 1 The book, as much as the post-conflict communities deemed, seeks reconciliation in different contexts, by different means and methods, where the notion of forgiveness is seen as a gatekeeper and affectively hardest to achieve. In a sense, the book portrays the post-genocidal memory space as a liminal stage between the precarity of post-conflict anomie and aspired social harmony that unravels with the reconciliation. In the liminal stage, the wounded communities don't necessarily wait for healing to come, but engage in the collective efforts to assemble the consensual narrative of the past sufferings that might convince the gatekeeper in their readiness to move on.

Contributing works in this book usher the reader into different political, historical, and socio-cultural contexts, detailing the merits and shortcomings of the variegated transitional processes that communities come up with in their quest for peace and concord. Based on the premise that "there is no forgiveness without truth just as there is no reconciliation without justice," 2 an ample number of chapters explore the implications and effects of the transitional justice processes in seeking forgiveness-particularly the works of the truth and reconciliation

\footnotetext{
1 Ajlina Karamehić-Muratović and Laura Kromják, eds., Remembrance and Forgiveness: Global and Interdisciplinary Perspectives on Genocide and Mass Violence (London: Routledge, 2020), ii.

2 Joshua R. Snyder, "Reconciling a Divided Society through Truth, Memory, and Forgiveness: Lessons from El Salvador and Guatemala," in Remembrance and Forgiveness: Global and Interdisciplinary Perspectives on Genocide and Mass Violence, ed. Ajlina Karamehić-Muratović and Laura Kromják (London: Routledge, 2020), 109.
}

Amina Hadžiomerović. "Book Review: Remembrance and Forgiveness: Global and Interdisciplinary Perspectives on Genocide and Mass Violence." Genocide Studies and Prevention 15, no. 1, 134-136. https://doi.org/ 10.5038/1911-9933.15.1.1820.

(C) 2021 Genocide Studies and Prevention. 
commissions (TRC) and the cases of bottom-up resistance to close the impunity gap. For example, these are explicated in the studies of transitional processes in Guatemala and El Salvador by Joshua Snyder; by Heribert and Kanya Adam in their analysis of the TRC pioneer in South Africa; and later on in the Suranjan Weeraratne's reflection on the collaborative truthseeking initiative by the former belligerents in Timor-Leste and Indonesia.

The violence sponsored by the communist regimes dominates the book, testifying to the fact that genocides and protracted social reluctance to forgive might be more characteristic of collectivist societies. By contrast, the first chapter written by the late Colin Tatz, reflecting upon the Australian process of coming to terms with the dark history through acknowledgment of the colonial massacre of Aborigines-as well as Kerri J. Malloy's account of the redemption through joint memorialisation of the genocide over the Native Americans in Northern Californiarepresent the rare examples in the volume where both sides have made a step towards the forgiveness.

Yet, my attention, presumably guided by my current research interests, has been drawn to the two ancillary themes that recurred throughout the book. These are the salience of multivocality of narratives and the local/cultural contextualisation of the genocides in the forgiveness-seeking processes; and the notion of gendered remembrance, notably the advocacy of greater involvement of women in the memorialisation of genocide and structural community healing. For example, Mery Kolimon, in the chapter on Indonesian Tragedy and protracted torture imputed by the totalitarian memory regime, advocates for the commemorative culture underpinned by the vernacular and polysemic memory narratives. Natalia Paula Crocco focuses on exploring the bridge between the state and people-the written media-and their role in the construction of Argentine cultural memory. Additionally, the importance of a locally and culturally tailored approach to teaching forgiveness is discussed in Ilham Nasser's and Mohammed Abu-Nimer's study of the Middle-Eastern schools and Alfred Sebit Lokuji's chapter on challenges of parochialism in the multi-ethnic South Sudan. Sterling Recker offers a particularly novel reflection on the Rwandan experimental approach to reconciliationenvisioned through village-based participation in the national economic development plan. All these chapters, in their own ways, exemplify the need for a more inclusive, multivocal, and culturally-contextualised approach to forgiveness and reconciliation in post-genocide milieus.

Similarly, in their comparative study of post-genocide memorialisation in Cambodia and Guatemala, JoAnn DiGeorgio-Lutz and Martha C. Galvan Mandujano poignantly critique the overwhelming essentialization of the women and their linking to the universal tropes of passive mourning mothers and helpless raped victims of the genocide, thus advocating for the greater inclusion of women both in representation and construction of the genocide memorials and commemorations. Likewise, Suranjan Weeraratne raised the issue of an overly masculinised portrayal of Timor Leste's violent history in TRC reports that engender an inadequate genocide memorialisation. Moreover, both Kolimon in the Indonesian example and Yuval Benziman in the Israeli-Palestinian context reflect upon women in action; the former illustrating mobilisation of female survivors' counter-narratives in the post-genocide rehabilitation, and the latter featuring the work of Israeli feminist anti-militarist NGO documenting the mistreatment of the Palestinians. All these authors insist on shifting the focus to women's agency and salience in post-conflict community recovery, memorialisation, and cultivation of forgiveness.

The afterword by David Pettigrew eruditely rounds off the whole volume by exemplifying the contemporary memory subversion and the social mutation of genocide denial in Bosnia into the whole new stage of "triumphalism" 3 whereby perpetrators humiliate the victims, celebrate their crimes, and glorify the war criminals, only further sabotaging any chance of forgiveness and interethnic reconciliation.

\footnotetext{
3 Hariz Halilovich, Globalization and Genocide (New York: Springer, 2017), 1-8; David Pettigrew, Afterword to Remembrance and Forgiveness: Global and Interdisciplinary Perspectives on Genocide and Mass Violence, ed. Ajlina Karamehić-Muratović and Laura Kromják (London: Routledge, 2020), 228.
} 
The teleological editing of the volume generates an interdisciplinary discourse on the subject matter, whereby the chapters concatenate in conversation by comparing and contrasting different perspectives and actions on the politics of memory and forgiveness in the aftermath of genocide. Arguably, the book does not mention nor praise a single case of fully achieved reconciliation, that prompts one to question whether true rapprochement is even possible; or rather, whether its precursor-the forgiveness-is ever anywhere fully attainable?

Contributions to this volume offer a timely reminder and testament that the current transitional and international justice mechanisms have not yet found a panacea for the postgenocide reconstruction, nor did their previous works in the post-war contexts lived up to the world's promise of never again that had been set in motion since the Holocaust-that upon editors' early notice takes a leave of absence from this book. The end result of the edited volume is an eclectic, well-balanced, and incisive exploration of the theoretically intricate and politically contested subject matter: the mobilisation of memory in seeking truth, justice, and forgiveness. Remembrance and Forgiveness is a deeply informative and comprehensive read, particularly useful for those who are interested in the interdisciplinary approach to post-conflict memory and genocide studies, transitional justice, and reconciliation. It is well-suited for upperundergraduate and graduate students, and may serve as a compendious overview of the current situation within the context of post-Holocaust genocides. 